\title{
Brasília: as controvérsias da utopia modernista na cidade das palavras
}

\author{
Eloísa Pereira Barroso
}

Curso: Doutorado em Sociologia

Data da defesa: 22 de agosto de 2008

Orientadora: Prof ${ }^{a}$. Dr ${ }^{\mathrm{a}}$. Barbara Freitag Rouanet

\section{Resumo}

Brasília: as controvérsias da utopia modernista na cidade das palavras é uma pesquisa que busca fazer emergir da "cidade das palavras" a "cidade real". Considera-se, aqui, que a justaposição do discurso sociológico ao discurso literário permite o desvelar 
de Brasília: a cidade modernista. Na tentativa de estabelecer uma leitura da cidade construída sob os preceitos da arquitetura modernista, procura-se nesta tese, sob o prisma de uma leitura sociológica, analisar os textos literários que têm Brasília como lugar para a tessitura da crônica, do conto, do romance e da poesia. Nas análises dos textos literários, procura-se a configuração de uma cidade moderna que, ao longo do seu processo de urbanização, passa por várias transformações. Nesta pesquisa, trabalha-se com a hipótese de que o texto literário é um locus privilegiado para se perceber o processo de "megalopolização" vivenciado pela cidade. Sensível às profundas transformações nas relações sociais que são responsáveis por transfigurar a racionalidade e a aura de metrópole modernista planejada, ele decodifica as metamorfoses por meio de uma linguagem subjetiva. Com sensibilidade, a cidade vista pela linguagem literária torna-se suporte para a imersão de estudos pertinentes à sociologia urbana. A "cidade-texto" capta o dinamismo da vida urbana e os diversos sentidos atribuídos à cidade. Assim, Brasília ora é utopia, ora é solidão, ora é a megalópole em construção. E é dessa diversidade de significações que a "cidade das palavras" produz a "fisiognomia" da "cidade real".

Palavras-chave: literatura; sociologia; cidade moderna. 